\title{
THE APPLICATION OF GEOBIOCOENOLOGICAL LANDSCAPE TYPOLOGY IN THE MODELLING OF CLIMATE CHANGE IMPLICATIONS
}

\author{
VERONIKA VLČKOVÁ ${ }^{1}$, ANTONÍN BUČEK ${ }^{2}$, IVO MACHAR ${ }^{3 *}$, TOMÁŠ DANĚK ${ }^{3}$, \\ VILÉM PECHANEC ${ }^{4}$, JAN BRUS $^{4}$, HELENA KILIANOVÁ ${ }^{4}$ \\ ${ }^{1}$ Czech Technical University in Prague, Faculty of Transportation Sciences, Dpt. of Applied \\ Informatics, Konviktská 20, 11000 Praha 1, Czech Republic \\ ${ }^{2}$ Dpt. of Forest Botany, Dendrology and Geobiocoenology, Faculty of Forestry and Wood \\ Technology, Mendel University in Brno, Zemedelska 3, 61300 Brno, Czech Republic \\ ${ }^{3,}$ Dpt. of Development Studies, Faculty of Science, Palacky University Olomouc, 17. \\ listopadu 12, 77146 Olomouc, Czech Republic, " corresponding author \\ ${ }^{4}$ Dpt. of Geoinformatics, Faculty of Science, Palacky University Olomouc, 17. listopadu 12, \\ 77146 Olomouc, Czech Republic
}

Received: $3^{\text {rd }}$ Septrember 2015, Accepted: $5^{\text {th }}$ October 2015

\begin{abstract}
Geobiocoenological landscape typology, which is used in landscape planning in the Czech Republic, includes vegetation zonation of the landscape. Vegetation zones are determined by climatic conditions. Changes in climatic conditions will probably be manifested in the shift of vegetation zones in the landscape. Mathematical geobiocoenological model of vegetation zonation of the landscape is based on the general ecological relationship between the current vegetation zonation and present climatic conditions and the assumption that this general relationship will be maintained in the future. The paper presents the application of the model using the example of the prediction of changes in climatic conditions for the Norway spruce (the first-generation of the model) and grapevine (the second-generation of the model) in the Czech Republic. In the case of the Norway spruce example, the model shows that the predicted changes in climatic conditions will prevent the cultivation of the spruce in the Czech Republic outside its natural range in mountainous areas. The results of the presented model for grapevine show significant enlargement of areas climatically suitable for growing grapes within the studied area.These examples demonstrate the potential for the application of geobiocoenological landscape typology in the modeling of the effects of climate change in the landscape.
\end{abstract}

Key words: Geobiocoenological model, climate change, grapevine, landscape, Norway spruce, shift in vegetation zones, Register of biogeography

\section{INTRODUCTION}

\section{Vegetation zones within geobiocoenological landscape typology}

The aim of geobiocoenological landscape typology (Zlatník, 1976) is the differentiation of natural (potential) state of geobiocoenoses in the landscape. Geobiocoenological landscape 
Vlčková V., Buček A., Machar I., Daněk T., Pechanec V., Brus J., Kiliánová H.: The application of geobiocoenological landscape typology in the modelling of climate change implications

typification is based on the application of the theory of geobiocoene type (Ambros, 1985). Geobiocoenological typification has recently been used in the Czech Republic primarily for designing and creation of territorial systems of ecological stability (Buček et al., 2007). Geobiocoenological typification is also a basis of the methodology of biogeographical differentiation of the landscape in geobiocoenological concept (Buček \& Lacina, 1979). The aim of landscape differentiation in geobiocoenological concept is to create a coherent set of data for landscape planning (Buček \& Lacina, 2006). Geobiocoenological survey of the Czech landscape utilizes the results of typological mapping of forests (Randuška et al., 1986) and a comprehensive survey of agricultural land (Němeček et al., 1967; Klečka et al., 1979) and creates a uniform basis for the entire landscape through their integration. Geobiocoenological classification system of the Czech Republic consists of 9 vegetation zones, 8 trophic ranges and inter-ranges, 6 hydric ranges and 170 groups of geobiocoene types.

The geobiocoenological classification system has superstructural and primary units. Vegetation zones and ecological ranges (trophic and hydric) represent superstructural units; groups of geobiocoene types represent primary units (Buček \& Lacina, 1999). The advantage of geobiocoenological landscape typification is a direct link between geobiocoenological characteristics of the landscape and cadastral territories within the so-called Register of biogeography (Machar, 2013). The Register of biogeography was created as part of integrated information system on territory and contains the description of geobiocoenological landscape characteristics (vegetation zones, hydric and trophic ranges) projected on individual cadastral territories (Vlčková, 2014).

Vegetation zones (APPENDIX 1) express the link between the differences in natural vegetation and the differences in altitudinal and exposure climate. Vegetation zonation depends above all on air and soil temperatures and on the amount and temporal distribution of precipitation. Transitions between individual vegetation zones are usually continuous, the boundaries are of diffuse character, sharp boundaries are rare. The contacts and the sequence of vegetation zones can be significantly modified by specific meso-climate. Especially in deep river valleys affected by climatic inversion, the order of vegetation zones can be also inversed.

Vegetation zones thus represent a spatial framework for the differentiation of climatic characteristics of the landscape (Bertrand et al., 2011). According to the current views, the present vegetation zones gradually stabilized during the postglacial evolution of Central European biota in the period of older subatlantic that had begun 800 - 500 BC (Jankovská, 1997). The distribution of individual vegetation zones in the Central European landscape therefore reflects the character of the orographically conditioned differences in climatic conditions and their fluctuations in the period substantially longer than the period for which the measurements of basic climatic characteristics are available (Ložek, 2012). Modeling of changes in vegetation zonation in the landscape is becoming increasingly important in the context of predicted climate change (Garamvoelgyi \& Hufnagel, 2013). Models of vegetation zones can be considered to be one of the fundamental knowledge bases to understand the significance of climate change for ecosystems (Walther, 2010). One of these models is the geobiocoenological model of vegetation zonation in the Czech Republic. The model is based on a general ecological relationship between the present vegetation zonation and the current climatic conditions and on the assumption that this relationship will be maintained also in the future. The projected climate change will, therefore, be manifested by a shift (change) in the climatic conditions of the current vegetation zones.

The aim of the present paper is to demonstrate possible use of vegetation zonation of the landscape for the creation of scenarios of potential impacts of predicted climate change on 
specific biological species - the case study deals with the Norway spruce growing conditions in the Czech Republic.

\section{THE FIRST-GENERATION GEOBIOCOENOLOGICAL MODEL OF THE SHIFT IN VEGETATION ZONES}

\section{Methodology of the first-generation model}

A mathematical model based on forecasting method of spatial analogies was created in the Czech Republic to develop scenarios of changes in vegetation zones due to climate change (Kopecká \& Buček, 1999). The model is designed as a set of special programs (FORTRAN programming language) and Arc/Info GIS applications. It is a static model which is not able to predict the speed of changes in vegetation in case of changes in climatic conditions.

Climatological basis for the first-generation geobiocoenological model of the shift in vegetation zones are maps of isolines of mean annual temperature and mean annual precipitation totals for the period 1960-1990 and prognostic maps of the Czech Republic for the year 2030. Definition points of the Biogeography register were assigned current climatic characteristics using digitized maps of isolines. The definition points were classified into the current vegetation zones according to available maps of vegetation zonation. In the next step the definition points were assigned climatic characteristics predicted for 2030 and the corresponding vegetation zones. Lang's rain factor, which is the ratio of average annual rainfall $(\mathrm{mm})$ and average annual temperature, was employed as a relationship indicator.

\section{Results of the first-generation model}

The analysis of changes in growing conditions of Norway spruce (Picea abies) - currently the most widespread tree species in forests of the Czech Republic - belong among the most important results (Fig. 1). According to the regional scenario developed by the model of the first generation, the share of forest land with conditions completely unsuitable for Norway spruce cultivation will increase from the current $6,25 \%$ to $31,65 \%$ in 2030 and the share of forest land with conditions unfavorable for spruce cultivation will increase from the current $14,27 \%$ to $28,32 \%$. The share of forest land with conditions favorable for spruce cultivation will decrease from the current $41,95 \%$ to $26,85 \%$ and the share of areas with very favorable climatic conditions will decrease from the current $37,17 \%$ to $13,17 \%$ of the forest land in 2030. Good and very good climatic conditions for Norway spruce will be preserved only in areas of its original natural occurrence in mountainous areas. According to the regional scenario, climatic conditions of the fifth vegetation zone and higher mountain zones will remain only in the highest mountains in 2030, in Bohemia in the Krušné hory Mountains, Slavkovský les, Český les, Šumava Mountains, Novohradské hory, Krkonoše, Jizerské hory, Králický Sněžník, and Orlické hory Mountains; in Moravia only in the Hrubý Jeseník and v Moravskoslezské Beskydy Mountains. 
Vlčková V., Buček A., Machar I., Daněk T., Pechanec V., Brus J., Kiliánová H.: The application of geobiocoenological landscape typology in the modelling of climate change implications

\section{Fig. 1: Predicted climatic conditions for Norway spruce in the Czech Republic in 2030} according to the results of the first-generation geobiocoenological model

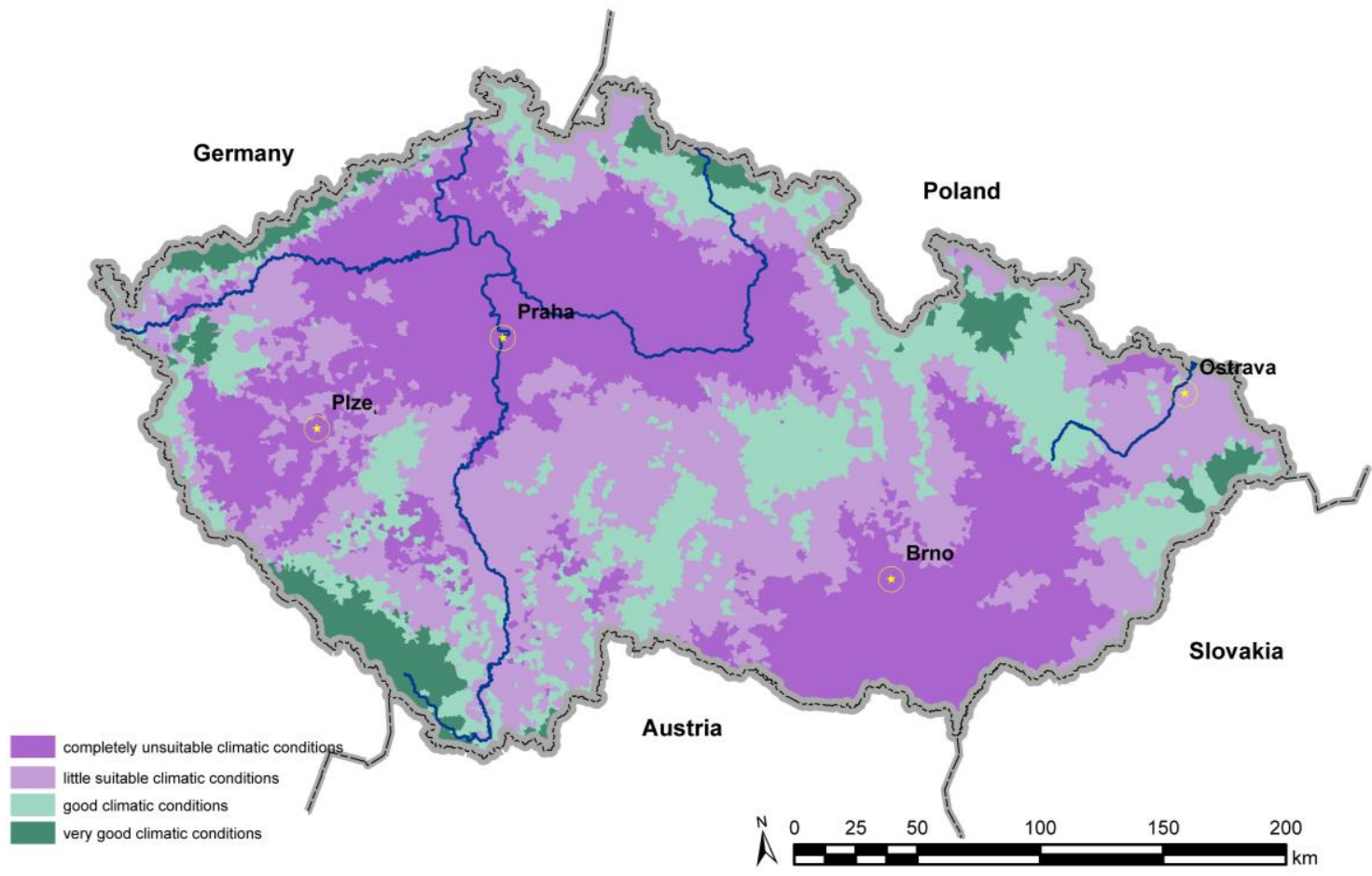

\section{The second-generation geobiocoenological model}

The second-generation geobiocoenological model uses the input climatic data from a validated database of the Czech Hydrometeorological Institute (CHMI) that links climatic data to a set of 131 points regularly spaced throughout the Czech Republic in the form of a regular trapezoidal network. The database of climatic elements was calculated by the ALADIN-CLIMATE.CZ model for the time period from 2010 to 2100 (Pretel, 2009) using the SRES A1B scenario (Nakićenović \& Swart, 2000). The definition points of the Biogeography register were assigned climatic characteristics using an analytic-geometric method designing a more detailed network of points in the area $(250 \mathrm{~m}$ step), to which the values of climatic variables were recalculated by the gradient method using the values relevant to four nearest neighbouring points of the original CHMI climatic database. Projected climatic characteristics of the definition points, the corresponding vegetation zones, and the characteristics of natural climatic conditions were determined using the method of space-time analogies, for which Lang's rain factor was used again as a relationship indicator. The output of the mathematical model for defined boundary conditions (climatic scenario for a specified time period, delimited geographic area, or algorithmized ecological conditions of a concrete plant species) provide scenarios of predicted future climatic conditions of vegetation zones in the landscape (see e.g. Kopecká et al., 2013).

The second-generation geobiocoenological model has been developed mainly for practical application in agriculture and forestry - e.g. changes in climatic conditions for the cultivation 
of grapevine (Vitis vinifera L.), for which the first vegetation zone provide optimal growing conditions in the Czech Republic, has been modelled recently (Fig. 2).

Fig. 2: Predicted delimitation of areas suitable for growing grapevine in the Czech Republic in 2030 time horizon - the results of the second-generation geobiocoenological model

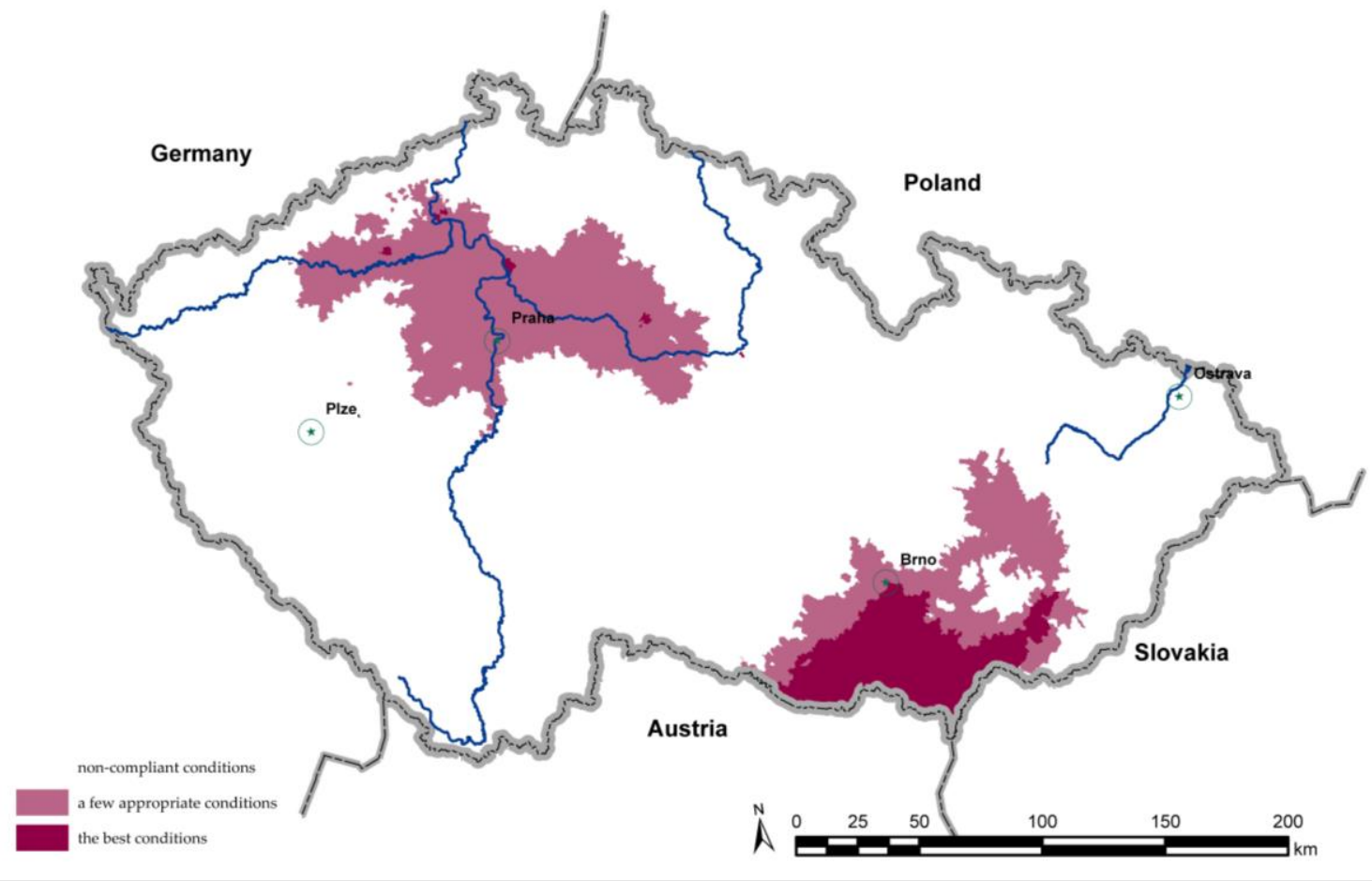

\section{DISCUSSION AND CONCLUSIONS}

In the Czech Republic the consequences of climate change will be most apparent in biocoenoses of the most common normal hydric range, which are bound to the hydric regime of soils and depend on the amount of atmospheric precipitation at individual sites (Trnka et al., 2011). The consequences of changes in climatic conditions will be less significant in biocoenoses of dry and limited hydric ranges at extremely hot and drying sites with a predominance of xerophilous S-strategists. Biocoenoses of waterlogged, wet and peat-bog hydric range with additional water will be also affected less dramatically.

The impact of climate change on vegetation will be first manifested at sites where ecological gradients form sharp boundaries between vegetation formations, e.g. at natural timberline. Significant changes can be expected on the border of the tundra and taiga; according to some models the area of the tundra biome may be reduced to two thirds of the current state when the amount of $\mathrm{CO}_{2}$ in the atmosphere doubles (Skre et al., 2002). A study of the shift of the timberline in the southern part of the Skanda Mountains in Sweden during the $20^{\text {th }}$ century led to the conclusion that the line shifted $100-165 \mathrm{~m}$ upwards for individual tree species, in the case of Scotch pine (Pinus sylvestris) it is now at its highest level in the last 4000 years. The shift of the timberline is explained by climate warming during the $20^{\text {th }}$ 
Vlčková V., Buček A., Machar I., Daněk T., Pechanec V., Brus J., Kiliánová H.: The application of geobiocoenological landscape typology in the modelling of climate change implications

century, a major part of the shift took place before 1950, further progress was identified in the 1990s (Kullman, 2001). The analysis of possible consequences of global climate change for boreal forests in the $21^{\text {st }}$ century led to the conclusion that in case of exceeding the limits of the current resilience of ecosystems, the changes in vegetation can be very fast and unexpected, often leading to the emergence of very different ecosystems (Chapin, 2004).

Non-dynamic correlative models based on the known relationship between the current climate and vegetation types are primarily used to predict changes in vegetation due to global climate change (Walker, 1994). These models do not predict the rate of changes in vegetation. The speed of anthropogenic climate change, which apparently has no analogy in the postglacial period, poses a big problem. According to the scenario that expects the temperature rise of $1-2^{\circ} \mathrm{C}$ in 2030 the isotherms move northwards at a speed of approximately 6-7 km per year in Central European conditions. The populations of trees as the main edificators of Central European natural biocoenoses, however, migrate 0,1 to 0,4 kilometers per year depending on their migration abilities (Csaba, 1997). Similar conclusions came from a detailed analysis of the impacts of global climate change and human activities on forest ecosystems in the context of postglacial evolution, current situation and future trends in Central Europe (Puhe \& Ulrich, 2001). The authors state that the predicted rate of warming is 15-40 times higher than the rate of changes of the Central European forest ecosystems in the postglacial period. Also a study focused on the changes of potential forest types in New England points out the difference between the speed of the shift in biological optimum of tree species due to warming and their migratory ability (Spencer, 2001). The results of a prediction model showed that the biological optimum would move more than $100 \mathrm{~km}$ for more than half of the tree species, and even $250 \mathrm{~km}$ for seven of the tree species, while historically determined speed of migration ranges between 10 and $50 \mathrm{~km}$ per one hundred years depending on the tree species.

In the context of the evaluation of potential impacts of climate change on forest geobiocoenoses and the landscape, it is important to consider the hierarchy of processes in ecosystems depending on the spatial and temporal scales. The progress and changes in physiological processes of individual organisms can be determined on a very short time scale (hours, days, weeks or months), and material cycles in annual cycles. The changes of processes and their consequences at the ecosystem and landscape level, however, show up on the scale of decades to centuries.

The hypothesis about the consequences of possible climate change impacts on biocoenoses and the landscape (Tuček et al., 2013) can be verified only by a long-term monitoring of the dynamics of natural biocoenoses in forest reserves. Therefore, it is necessary to continue repeated studies on research plots and polygons that were delimited in past and carefully evaluate the results of all studies that can help to clarify the consequences of the impacts of climatic factors and their changes on organisms, geobiocoenoses and the landscape. Therefore, the network of permanent research plots that was established in the 1930s by prof. A. Zlatník in the current Transcarpathian Ukraine is of extraordinary importance. Repeated studies performed in research plot no. 11 in the Pop Ivan Maramures Mountains led to the conclusion that the altitudinal distribution of tree species, especially beech (Fagus sylvatica) and silver fir (Abies alba), evinces an upward shift, (Buček et al., 2008).

The issue of global climate change has an important position in the wider context of the environment on our planet. Reactions to climate change include both mitigation measures aimed at reducing greenhouse gas emissions, and adaptation measures consisting in adapting land use to new climatic conditions (Trnka et al., 2012). If the projected climate change scenarios are fulfilled, the ecological manifestations of these changes in the Czech Republic are likely to match the regional scenario of changes in vegetation zonation. We should not 
underestimate the results of projected scenarios. Already at present it is useful to observe the precautionary principle and adjust land management so that any climate change would not have catastrophic consequences.

\section{ACKNOWLEDGEMENT}

The authors wish to thank the staff members of the Czech Hydrometeorological Institute J. Pretel and R. Tolasz for providing climatological data from the project „Refining Estimates of the Impacts of Climate Change on Water Management, Agriculture and Forestry and Proposals for Adaptation Measures“ (MŽP VaV SP/1a6/108/07).

This study was co-financed by the project of European Social Fund and the state budget of the Czech Republic (POST-UP II, CZ.1.07/2.3.00/30.0041).

\section{REFERENCES}

Ambros Z. (1985). Bioindikace abiotického prostředí lesních ekosystémů. Acta Universitatis Agriculturae Brno. 54(3-4), 367-392.

Bertrand, R., Lenoir, J., Piedallu, C., Riofrio-Dillon, G., de Ruffray, P., Vidal, C., Pierrat, J. C., Gegout, J. C. (2011). Changes in plant community composition lag behind climate warming in lowland forests. Nature. 479, 517-520.

Buček, A., Lacina, J. (1979). Biogeografická diferenciace krajiny jako jeden z ekologických podkladů pro územní plánování. Územní plánování a urbanismus. 6, 382-387.

Buček, A., Lacina, J. (1999). Geobiocenologie II. MZLU, Brno.

Buček, A., Lacina, J. (2006). Biogeografická diferenciace v geobiocenologickém pojetí a její využití v krajinném plánování. In: Dreslerová, J. \& Packová, P. (eds.), Ekologie krajiny a krajinné plánováni (18-29). Sborník ekologie krajiny 2. Lesnická práce, Kostelec nad Černými lesy.

Buček, A., Hrubý, Z., Lacina, J. (2008). Long-term research of natural forests on permanent plots founded by prof. A. Zlatník in protected areas of Transcarpathia. In: Proceed. of the Int. Conf. Carpathian Biosphere Reserve (80-94), Rakhiv.

Chapin, L. (2004). Global change and the boreal forest: tresholds, shifting states or gradual change? Ambio, 33, 6, 361-365.

Csaba, M. (1997). Conservation of genetic resources in a changing world - strategy considerations for temperate forest tree species. Proc. XI. World Forestry Congress, Antalya. Vol. 2, 195-201.

Garamvoelgyi, A., Hufnagel, L. (2013). Impacts f climate change on vegetation distribution no.1. Climate change induced vegetation shifts in the Palearctic region. Applied Ecology and Environmental Research. 11, 1, 79-122.

Jankovská, V. (1997): Vývoj vegetace střední Evropy. Lesnická práce. 76, 11, 409-412.

Klečka, M. (ed.) (1979). Principy bonitace zemědělského půdního fondu a soustava bonitovaných půdněekologických jednotek ČSR. Rostlinná výroba, 25.

Kopecká,V., Buček, A. (1999). Modelování možných důsledki̊ globálních klimatických změn na územi České republiky. Záv. Zpráva pro AOPAK ČR Praha. 27 pp, 13 maps.

Kopecká, V., Machar, I., Buček, A., Kopecký, A. (2013). The Impact of Climate Changes on 
Vlčková V., Buček A., Machar I., Daněk T., Pechanec V., Brus J., Kiliánová H.: The application of geobiocoenological landscape typology in the modelling of climate change implications

Sugar Beet Growing Conditions in the Czech Republic. Listy cukrovarnické a řepařské. 129, 11, 326-329.

Kullman, L. (2001). 20th century climate warming and tree-limit rise in the Southern Scandes of Sweden. Ambio. 30, 2, 72-80

Ložek, V. (2012). Důsledky poznání vývoje př́rody a krajiny ČR v holocénu. In: Machar, I., Drobilová, L. (eds.): Ochrana př́rody a krajiny $v \check{C} R$ (58-64). Univerzita Palackého, Olomouc.

Machar, I. (2013): Applying of the Biogeography Register to Predicting the Consequences of Global Climate Changes on the Landscape in the Czech Republic. In: Proceedings of the $11^{\text {th }}$ Int. Conference on Environment, Ecosystems and Development (15-18). Brasov, Romania.

Nakićenović, N., Swart, R. (2000). Special Report on Emissions Scenarios. A Special Report of Working Group III of the IPCC. Cambridge Univ. Press, New York. 612 s.

Němeček, J. (ed.) (1976). Průzkum zemédělských půd ČSSR. MZV Praha.

Pretel J. (2009). Současný vývoj klimatu a jeho výhled. Ochrana přírody. Suppl., 46, 2-7.

Puhe, J., Ulrich, B. (2001). Global climate change and human impacts on forest ecosystems: postglacial development, present situation, and future trends in Central Europe. Ecological Studies. 143, 592 pp.

Randuška, D., Vorel., J., Plíva, K. (1986). Fytocenológia a lesnícka typológia. Príroda, Bratislava.

Skre, O., Barter, R., Ceaford, R.M.M., Callaghan, T.V., Fedorkov, A. (2002). How will the tundra-tajga interface respond to climate change? Ambio. Special report 12, Tundra-tajga treeline research, 37-46.

Spencer, S. (2001). Current and future potential forest cover types. In: New England Regional Assessment Group: Preparing for a changing climate: the potential consequences of climate variability and change (47-48). New England Overview. University of New Hampshire. Case study 4.

Trnka, M., Brázdil, R., Dubrovský, M., Semerádová, D., Štěpánek, P., Dobrovolný, P., Možný, M., Eitzinger, J., Málek, J., Formayer, H., Balek, J., Žalud, Z. (2011). A 200 -year climate record in Central Europe: implications for agriculture. Agronomy for Sustainable Environment. 31, 4, 631-641.

Trnka, M., Brázdil, R., Olesen, J. E., Eitzinger, J., Zahradníček, P., Kocmánková, E., Dobrovolný, P., Štěpánek, P., Možný, M., Bartošová, L., Hlavinka, P., Semerádová, D., Valášek, H., Havlíček, M., Horáková, V., Fischer, M., Žalud, Z. (2012). Could the Changes in regional crop yields be a pointer of climatic change? Agricultural and Forest Meteorology. 166-167, 62-71.

Tuček, P., Caha, J., Janoška, Z., Vondráková, A., Samec, P., Voženílek, V., Bojko, J. (2013): Forest vulnerability zones in the Czech Republic. Journal of Maps. 10, 1, 179-182.

Vlčková, V. (2014). Systémový charakter modelování možných trendů důsledků klimatických změn nástroji geografických informačních systémů. Acta Informatica Pragensia. 3, 1, 70-88.

Walther, G.R. (2010). Community and ecosystem responses to recent climate change. Philosophical transactions of the Royal society B - Biological Sciences. 365 (1549), 2019-2024.

Walker, B.H. (1994). Landscape to regional scale responses of terrestrial ecosystems to global change. Ambio. 23, 1, 67-73 


\section{APPENDIX I}

\section{Vegetation zones within geobiocoenological landscape typology}

\section{The first (oak) vegetation zone}

The oak vegetation zone includes geobiocoenoses of the warmest and hottest areas of the Czech Republic, characterized by the representation of species of Ponto-Pannonian and Sub-meditterranean geoelement, some of which do not protrude into higher vegetation zones. The oak vegetation zone is continuously distributed in South Moravia in the territory that belongs to the Pannonian biogeographic province. It also occurs in smaller, often isolated areas in Moravia in biogeographic regions adjacent to the Pannonian province, especially in the foothills of the Českomoravská vrchovina Highlands and the southern parts of the Moravian Karst. In Bohemia, extra-zonal locations with significantly thermophilic biota belong to the oak vegetation zone, especially in the floodplains of the Elbe and the Ohře River, in the České Středohoří Mountains, and on warm limestone areas of the Bohemian karst. The oak zone covers only 3\% of the total area of the Czech Republic.

The oak zone spreads in lowlands, hilly areas, and warmest parts of the rugged highlands generally to the altitude of $300 \mathrm{~m}$ a.sl., exceptionally up to about $500 \mathrm{~m}$ a.s.l. (e.g. Děvín Hill in the Pavlovské vrchy). The landscape of the oak zone is characterized by a continuous occurrence of loess soils with chernozem. Deep fluvisols formed in historical period by the sedimentation of flood loams on the Pleistocene gravel bedrock occur in broad river floodplains. Biocoenoses of the first vegetation zone typically occur also on warm and dry soils on alkaline rocks, mainly on limestones and serpentines.

The climate is subcontinental, warm, with larger temperature amplitudes and frequent occurrence of dry periods. The average annual temperature is around $9^{\circ} \mathrm{C}$. The average annual rainfall is very low, usually around $500 \mathrm{~mm}$. The growing season is very long, longer than 170 days. Geobiocoenoses of the first oak vegetation zone occur continuously in the warm climatic area $\mathrm{T} 4$, in patches in $\mathrm{T} 2$ and adjacent moderately warm areas.

\section{The second (beech-oak) vegetation zone}

Geobiocoenoses of this zone are continuously distributed in warm dry to moderately wet areas and are characterized by the occurrence of both thermophilic species of Ponto-Pannonian geoelement and species typical of Central European broad-leaved forests. In Moravia, the biocoenoses of the second vegetation zone line the area of the continuous occurrence of oak zone in South Moravia, they prevail in Central Moravia in Hornomoravský úval and the adjacent rolling areas. In Bohemia, they occupy most of the floodplain of the Elbe and lower reaches of the Vltava River. The second vegetation zone is continuously distributed in the Most basin and on the southern slopes of the České středohoří Mountains. A typical feature of geobiocoenoses of this zone is the penetration on sunny slopes of the deep river incisions into the heart of hilly areas and highlands with prevailing higher vegetation zones. The beech-oak vegetation zone occupies $12 \%$ of the total area of the Czech Republic.

The beech-oak vegetation zone spreads in lowlands, hilly areas and highlands ranging from 200 to 400 (500) $\mathrm{m}$ a.s.l. Soil forming bedrock is very diverse; loess and loess loam with black and brown earths are frequent. The predominant soil types, however, are different subtypes of cambisols and luvisols on the most diverse bedrocks, often with deluvium or shallow loess loam overlays. Broad river floodplains with fluvisols formed in historical period by the sedimentation of flood loams are rather frequent in this zone too. 
Vlčková V., Buček A., Machar I., Daněk T., Pechanec V., Brus J., Kiliánová H.: The application of geobiocoenological landscape typology in the modelling of climate change implications

Continuous occurrence of the second vegetation zone is linked to warm climatic area T2. The annual average temperature is around $8^{\circ} \mathrm{C}$. The average annual rainfall is diverse. It is low in areas of the rain shadow (even below $500 \mathrm{~mm}$ ), in areas of normal rainfall it is 550 $600 \mathrm{~mm}$ and more. The length of the growing season is about 165 days.

\section{Dry (xeric) variant of the beech-oak vegetation zone}

The presence of beech trees is problematic in natural forest geobiocoenoses in areas with a lack of rainwater (with an average annual rainfall of less than 500 resp. $550 \mathrm{~mm}$ ). Beech trees would probably not be part of natural tree composition in dry areas, even in normal hydric range. This assumption, however, cannot be reliably proved today because the predominant area of the dry territories has been converted to field biocenoids since the Neolithic era.

\section{The third (oak-beech) vegetation zone}

Tree species of the Central European broad-leaved forest predominate in geobiocoenoses of this vegetation zone. Thermophilic species of lower vegetation zones disappear, some sub-montane species are rarely found. In Bohemia, geobiocenoses of the third vegetation zone line the continuous occurrence of the second vegetation zone in Česká tabule, they prevail in Džbán, Rakovnická pahorkatina and Křivoklátská vrchovina. A more continuous occurrence is in the Plzeň basin and its wider surroundings, in the České Středohoří Mountains and in valley incisions of the middle reaches of the Vltava and Ohře Rivers. In Moravia, the third vegetation zone prevails in the Středomoravské Karpaty Mountains, the central part of the Bílé Karpaty Mountains, and in the foothills of the Českomoravská vrchovina Highlands. A more continuous occurrence is in the foothills of the Nízký Jeseník Mountains, in Zábřežská vrchovina, the Moravian Gate, and in lower parts of the Podbeskydská pahorkatina. In Silesia, geobiocoenoses of the third vegetation zone prevail in the Opavská pahorkatina. The oak-beech vegetation zone occupies $18 \%$ of the total area of the Czech Republic.

The third vegetation zone occurs on plateaus, in hilly areas and highlands, usually between 300 and $500 \mathrm{~m}$ a.s.l., in warm locations even above $600 \mathrm{~m}$ a.s.l. Layers of loess loam can be found locally on the most diverse soil forming bedrocks. The prevailing soil types include cambisols and deep loam fluvisols in river floodplains. Rankers on debris are more frequent than in lower vegetation zones.

Continuous occurrence of the second vegetation zone is linked to moderately warm climatic areas, especially MT9, MT10, and MT11. The climate can be described as moderately warm, moderately dry, with mild winters. The average annual temperature is around $7.5^{\circ} \mathrm{C}$, the growing season lasts $150-160$ days. The average annual rainfall of $600-650$ $\mathrm{mm}$ has been reduced below $550 \mathrm{~mm}$ in the last decades. The period with frost days (120 days) and the duration of the snow cover (60 days) is longer than in the first and second vegetation zones.

\section{The fourth (beech) vegetation zone}

Tree species of the Central European broad-leaved forest typically predominate in geobiocoenoses of the fourth vegetation zone, thermophilic species of Ponto-Pannonian geoelement are not found any more, the occurrence of a number of sub-montane species, often belonging to sub-boreal or boreal geoelement, is typical. The character of beech zone biocoenoses is somewhat different in the Hercynian and Carpathian parts of the Czech Republic.

Biocoenoses of more fertile substrates dominated by meso- to nitrophilous species predominate in the Carpathian part of the country, while in the Hercynian part biocoenoses of 
poorer substrates prevail, with species of acidophilic inclination, where the competition ability of the beech as a leading tree species of this vegetation zone is usually lower. Biocoenoses of this zone occur continuously in highlands and lower parts of mountain areas in South, North and East Bohemia. In the Hercynian part of Moravia, they typically occur in large parts of the Českomoravská vrchovina and Drahanská vrchovina Highlands and in the Nízký Jeseník Mountains. In the Carpathian part of Moravia, larger segments of beech zone can be found in the Chřiby and Bílé Karpaty Mountains and in the Hostýnsko-vsetínská and Vizovická vrchovina Highlands. Beech vegetation zone is the most common in the Czech Republic; it covers $36 \%$ of the total area of the country.

The fourth vegetation zone occurs in rugged highlands and mountainous areas, usually between 400 and $700 \mathrm{~m}$ a.s.1., in the Carpathian part of Moravia even above $800 \mathrm{~m}$ a.s.l. The prevailing soil types include cambisols on the most diverse soil forming substrates. Continuous occurrence is linked to moderately warm climatic areas, especially MT3, MT5, and MT7. The average annual temperature is around $7{ }^{\circ} \mathrm{C}$, the average annual precipitation is about $700 \mathrm{~mm}$, the length of the growing season is about 140 to 150 days. Climate has sub-oceanic character with less marked amplitude of annual and daily temperatures. It can be described as moderately warm, moderately humid, with mild winters. The number of frost days is 130 , snow cover lasts about 80 days. The character of climatic conditions, which show oceanic tendency without extremes in temperature or humidity that are typical of continental climate, corresponds to the ecological optimum of the beech.

\section{Oak-conifer variant of the beech vegetation zone}

Oak-conifer variant of the third and fourth vegetation zones is defined for specific areas of the Hercynian part of the Czech Republic, where the competition ability of beech trees is significantly reduced due to specific climate and soil conditions, as acidic waterlogged soils occur over continuous areas. The character of biocoenoses of the so called Central European taiga is similar to the character of the major part of the North European lowlands and hilly areas and waterlogged parts of European taiga. In contrast to the oak-beech and beech zones, the tree level is formed mainly by oak trees and conifers. The occurrence of many sub-montane to montane species of boreal and boreo-continental geoelement is typical, even at lower altitudes.

Typical regions with the continuous occurrence of the oak-conifer variant include South Bohemian basins, Ostrava basin and basins within the Ralská pahorkatina uplands. The oak-conifer variant of the third and fourth vegetation zones covers $5 \%$ of the total area of the Czech Republic.

It occupies mostly wide open flat to slightly indented basins, plateaus, and rolling hills surrounded by higher mountains, at the altitude of about $400 \mathrm{~m}$ a.s.l., in the Ostrava basin and the Ralská pahorkatina uplands even below $300 \mathrm{~m}$ a.s.l. The bedrock consists of lacustrine, marine or glacio-fluvial sediments, mainly sands and clays. Due to high level of underground water gley soils prevail, mainly sour pseudogleys and gleys poor in minerals. Deep peat soils are frequent, podzols occur at sites of elevated relief. In contrast to the beech zone, local increase in the continentality of the climate is manifested in large inverse areas with frequent late frosts. High water content contributes to the colder character of the soil. Areas classified as oak-conifer vegetation zone belong mainly to moderately warm area MT10, partly to MT9 and MT11.

\section{The fifth (fir-beech) vegetation zone}

The fir-beech vegetation zone can be described as a first mountain zone because of regular occurrence of many sub-montane to montane species. The share of species of boreal and 
Vlčková V., Buček A., Machar I., Daněk T., Pechanec V., Brus J., Kiliánová H.: The application of geobiocoenological landscape typology in the modelling of climate change implications

sub-boreal geoelement exceeds the share of species of Central European deciduous forest. Biocoenoses of the fifth vegetation zones occur continuously in all higher border mountains in the Hercynian part of the Czech Republic (the Novohradské hory, Šumava, Český les, Krušné hory, Lužické hory, Jizerské hory, Krkonoše, Orlické hory, Králický Sněžník, Hrubý Jeseník Mountains). In the interior of the country, different sized segments occupy the Slavkovský les, Brdská vrchovina and Plánický hřbet Mountains, and upper parts of the Votická vrchovina, Železné hory, Českomoravská vrchovina (Žd'árské vrchy and Javořická vrchovina), Drahanská vrchovina, Zábřežská vrchovina, and Nízký Jeseník Mountains. In the Carpathian part of Moravia, the fir-beech zone prevails in the Beskydy, Hostýnské vrchy, Vsetínské vrchy, and Javorníky Mountains and in the most elevated positions of the northern part of the Bílé Karpaty Mountains. The fir-beech zone occupies $22 \%$ of the Czech Republic, it is the second most abundant vegetation zone in the country.

The fir-beech zone occupies upper parts of highlands and middle parts of mountains, mainly between the altitude of (500) 600-800 (900) $\mathrm{m}$ a.s.l. Cambisols prevail on various crystalline rocks and the Carpathian flysch, rusty brown podzolic soils, known as cryptopodzols, appear in the most elevated areas. High proportions of gley cambisosls, pseudogleys, gleys, and peaty soils are typical of the Hercynian part of the Czech Republic.

The center of the fir-beech zone distribution is in the cold climatic areas, especially in $\mathrm{CH} 7$, and it also occurs in cooler and precipitation rich parts of moderately warm area MT3. The average annual temperature is around $6^{\circ} \mathrm{C}$, the average annual rainfall ranges between 700 and $1000 \mathrm{~mm}$, most often around 750 to $800 \mathrm{~mm}$. From the viewpoint of hydric regime it is important that, contrary to the lower vegetation zones, the horizontal precipitation is starting to exceed the interception. The duration of snow cover is 100 to 120 days which is significantly longer than in lower vegetation zones. The number of frost days is 140 to 160 . The length of the growing season does not exceed 140 days.

\section{The sixth (spruce-fir-beech) vegetation zone}

Mountain species, often belonging to sub-boreal, boreal, and exceptionally sub-arctic geoelement start to prevail in this vegetation zone. Species of Central European deciduous forests disappear. Biocoenoses of the sixth vegetation zone occur at higher altitudes of border Hercynian mountains (the Novohradské hory, Šumava, Český les, Slavkovský les, Krušné hory, Jizerské hory, Krkonoše, Orlické hory, Králický Sněžník, and Hrubý Jeseník Mountains) and also at the highest altitudes of the Beskydy Mountains. In contrast to lower vegetation zones, the representation of the sixth zone in the Czech Republic is significantly lower; it covers less than $3 \%$ of the total area of the country.

A more continuous distribution is concentrated at higher altitudes of mountains, usually between 900 and $1200 \mathrm{~m}$ a.s.l. Predominant soil types include podzolic soils (humic podzols, peaty podzols, cryptopodzols) on different crystalline rocks and Carpathian flysch. Pseudogleys and peaty soils occur in large areas in the Hercynian part of the Czech.

The sixth vegetation zone occurs in cold montane climatic areas, mainly in CH6. The average annual temperature is around $5^{\circ} \mathrm{C}$, the average annual rainfall is $900-1100 \mathrm{~mm}$. The humidity of the climate is significantly increased by the horizontal precipitation from fog and frost. The cold mountain climate is reflected in the duration of snow cover, which ranges between 110 and 130 days, and the number of frost days (150 to 160). The growing season is already relatively short (120 to 130 days).

\section{The seventh (spruce) vegetation zone}

The biocoenoses of this vegetation zone have the character of mountain spruce taiga dominated by montane and boreal species. Species of Central European deciduous forest are 
very rare. It is the last vegetation zone with a continuous formed synusia of woody plants in the form of trees. The biocoenoses of the spruce vegetation zone characteristically form the upper forest border. In the Czech Republic, this is true only in the Krkonoše, Králický Sněžník and Hrubý Jeseník Mountains. Segments of this vegetation zone occupy the most elevated areas of the Šumava, Krušné hory, Jizerské hory, and Moravskoslezské Beskydy Mountains. In total, the spruce vegetation zone covers only less than $1 \%$ of the area of the Czech Republic.

Continuous, but more often only patchy distribution is concentrated in the most elevated areas in mountains, at the altitudes ranging between (1000) 1100 and $1350 \mathrm{~m}$. Patchy distribution on isolated mountain tops is typical. Humic podzols are the predominant soil type on crystalline rocks and on flysch in the Beskydy Mountains.

The climate is cold, mountainous, corresponding to climatic area $\mathrm{CH} 4$. The annual average temperature is less than $3.5^{\circ} \mathrm{C}$, the amount of rainfall is high - the average annual precipitation is generally higher than $1200 \mathrm{~mm}$. The duration of snow cover is very long, more than 150 days, frost days can occur over a half of the year (170 days) and, therefore, the growing season is very short, less than 100 days. Biocoenoses are affected by winds and high amounts of horizontal precipitation.

\section{The eight (mountain pine) vegetation zone and its spruce variant}

This zone includes areas above the upper forest border including patches of primary treeless alpine vegetation of the ninth vegetation zone. The occurrence of many arcto-alpine species, often relicts, is typical. The zone occurs at the highest altitudes of the Krkonoše Mountains; the spruce variant at the highest altitudes of the Hrubý Jeseník and Králický Sněžník Mountains.

The zone occupies the most elevated parts of the Krkonoše, Hrubý Jeseník, and Králický Sněžník Mountains, usually places above $1300 \mathrm{~m}$ a.s.l. that are significantly influenced by the effects of the peak phenomenon and anemo-orographic systems (Jeník, 1961). On the basement crystalline rocks, the soils are usually shallow and stony, of the character of rankers, mountain podzols and locally even polygonal soils or peat organic soils.

The average annual temperature is very low (below $1,5^{\circ} \mathrm{C}$ ), the average annual rainfall is very high (above $1500 \mathrm{~mm}$ ), the growing season is very short (up to 60 days). The duration of snow cover is longer than 170 days and the number of frost days exceeds 190. The zone occurs in the coldest and windiest patches of climatic area $\mathrm{CH} 4$. 